\title{
The effect of pumpkin flour on quality and acoustic properties of extruded corn snacks
}

\author{
Natalia Poliszko ${ }^{1}$ Przemysław Łukasz Kowalczewski $^{2}$ (D) $\cdot$ Iga Rybicka $^{3}$ (D) $\cdot$ Piotr Kubiak $^{4}$ (D) \\ Stefan Poliszko ${ }^{5}$
}

Received: 9 August 2018/Revised: 17 January 2019/Accepted: 4 February 2019/Published online: 19 February 2019

(C) The Author(s) 2019

\begin{abstract}
Significant amounts of minerals, vitamins, carotenoids and other bioactive substances, as well as documented healthpromoting activity, make pumpkin flour (PF) an interesting food additive. In this article, the influence of PF addition (2\% and $4 \%$ ) on quality, acoustic and textural properties, colour, potential renal acid load (PRAL) and consumer acceptance of extruded corn snacks was evaluated. The results showed that PF addition can be used for production of sensorily attractive extrudates with lowered acidity. However, changes in the general characteristics of extrudates were observed. The expansion ratio and water solubility index decreased, while the bulk density and water absorption index increased. Changes of colour were observed as well. PF addition resulted in significantly decreased hardness and breaking force index. Moreover, the acoustic properties (total loudness, crackliness, crispness and crunchiness) of the extrudates produced with PF were different from the control. The total loudness, crackliness, crispness as well as crunchiness in extrudates enriched with PF significantly decreased ( $\mathrm{p}<0.005)$ with increasing percentage of PF in the product. Nevertheless, the results of the consumer study indicated that the addition of PF improved the taste and appearance of extrudates, thus increasing the overall acceptability of the final product.
\end{abstract}

Keywords Corn extrudates $\cdot$ Pumpkin $\cdot$ Extrusion $\cdot$ Acoustic emission $\cdot$ Texture $\cdot$ Minerals $\cdot$ Potential renal acid load

Przemysław Łukasz Kowalczewski

przemyslaw.kowalczewski@up.poznan.pl

1 Students' Scientific Club of Food Technologists, Faculty of Food Science and Nutrition, Poznań University of Life Sciences, Poznań, Poland

2 Institute of Food Technology of Plant Origin, Faculty of Food Science and Nutrition, Poznań University of Life Sciences, Poznań, Poland

3 Department of Technology and Instrumental Analysis, Faculty of Commodity Science, Poznań University of Economics and Business, Poznań, Poland

4 Department of Biotechnology and Food Microbiology, Faculty of Food Science and Nutrition, Poznań University of Life Sciences, Poznań, Poland

5 Research and Development Centre of Research, Didactic Equipment COBRABiD Ltd., Warsaw, Poland

\section{Introduction}

Over recent decades, consumer requirements for food products have changed significantly. Consumers expect that today's food will not only satisfy hunger and provide necessary nutrients, but will also prevent nutrition-related diseases and improve physical and mental condition (Betoret et al. 2011; Goetzke et al. 2014). There is also a growing interest in ready-to-eat products, for example extruded corn snacks. The high consumer attractiveness as well as the low manufacturing costs make them a good matrix for creating functional and healthy food. They are often enriched with various nutrient-dense ingredients (Dehghan-Shoara et al. 2010; Makowska et al. 2013; Peressini et al. 2015; Oniszczuk et al. 2015). Pumpkin is rich in different nutrients. Low carbohydrate and fat contents make it a low calorie and easily digestible raw material (Zdrojewicz et al. 2016). It is characterised by high nutritional value that results from a high content of minerals, vitamins: A, C, niacin, thiamine, riboflavin and it is also a 
rich source of carotenoids and other bioactive substances, such as phenolic compounds (Akwaowo et al. 2000; Caili et al. 2006; Cerniauskiene et al. 2014). Moreover, it contains significant quantities of alkalizing elements such as potassium, calcium or magnesium, which positively affect the acid-alkaline balance of the body. In addition, it has shown anti-carcinogenic and anti-sclerotic properties (Caili et al. 2006; Yadav et al. 2010). Increased pumpkin consumption can also play an important role in the prevention of hypertension (Kwon et al. 2007).

Extrusion cooking is a high temperature (up to $220{ }^{\circ} \mathrm{C}$ ) process that uses short processing periods (HTST: High Temperature Short Time). The parameters of the process determine the extent to which thermolabile nutrients and bioactive compounds are degraded. Proper selection of extrusion parameters not only allows preserving nutritional value but also can improve the bioavailability of certain bioactive compounds. Zielinski et al. (2001) reported that extruded cereal products contained three times as much ferulic acid as products obtained using traditional methods. Similarly, the content of total phenolic compounds was increased in extruded products with vegetable additives (Shih et al. 2009; Stojceska et al. 2008). Such changes are a result of forces exerted on the raw material during the extrusion process.

The most commonly used raw materials for extrusion are cereal products containing starch and protein, such as corn, rice or wheat (Dehghan-Shoara et al. 2010; Gumul et al. 2011; Guy 2001). Addition of small amounts of vegetables into extruded cereal snacks not only enriches it in health-promoting bioactive compounds, but may also improve the taste, smell or appearance of extrudates. The sensory and textural properties of extrudates are critical to consumer acceptance (Szczesniak 2002). The production of attractive extrudates with desired characteristics can be obtained by proper selection of the extrusion conditions (Lazou and Krokida 2010; Lazou et al. 2010). The simultaneous effect of high temperature, high pressure and mechanical shear causes cooking and plasticization of the raw material and at the same time creates the characteristic fragile and crunchy structure of thus obtained products. Acoustic emission accompanying consumption is also an important sensory property (Chauvin et al. 2008). Consumers usually associate food products with noticeable acoustic emission with positive, healthy and fresh food. Lacking acoustic properties suggest poor quality and often lead to the loss of consumer acceptance (Salvador et al. 2009; Stangierski et al. 2016; Van Hecke et al. 1998).

Therefore, the aim of this study was to determine the effect of pumpkin flour on physical and acoustic properties of extruded corn snacks. A consumer acceptance evaluation was performed in order to supplement the results of instrumental analyses.

\section{Materials and methods}

\subsection{Materials}

Corn grits (CG) with a granulation of $850-1250 \mu \mathrm{m}$ were purchased from Grygier Corn Mill (Wonieśc, Poland). Pumpkin flour $(\mathrm{PF})$ was obtained from The Cooperative of Organic Agriculture Products "Dolina Mogilnicy" (Wolkowo, Poland).

\subsection{Preparation of extrudates}

CG were mixed with pumpkin flour in the following ratios: PFE2: 2\% PF/98\% CG, PFE4: 4\% PF/96\% CG. The control corn extrudates (denoted as $\mathrm{C}$ ) were prepared without addition of PF. PF and CG were mixed and then the level of raw material was established at $18 \%$. All the extrudates were prepared with the use of an S-45 single-screw extruder (Metalchem, Gliwice, Poland). The L:D ratio was 12:1, the screw diameter: $45 \mathrm{~mm}$ and length: $550 \mathrm{~mm}$ and compression rate of $3: 1$. The maximum motor power $14 \mathrm{~kW}$ and the capacity of the extruder was $25 \mathrm{~kg} /$ hour. A die with round hole of $3.5 \mathrm{~mm}$ diameter was placed at the end of the barrel. The following processing conditions were applied: temperature: section I $135^{\circ} \mathrm{C}$; section II $180{ }^{\circ} \mathrm{C}$; head $135^{\circ} \mathrm{C}$; screw rotations $75 \mathrm{rpm}$. Following extrusion, the extrudates were packed in polypropylene pouches and stored at room temperature.

\subsection{Chemical composition and water activity}

The nitrogen content was determined using Kjeldahl method according to PN-EN ISO 20,483 and was used to calculate the protein content by multiplying the result by the conversion factor of 6.25 . The ash content was determined according to AACC Method 08-01.01. Measurements of water activity were performed according to ISO Method 18,787 (2017) with the use of AquaPro Water Activity Meter (Decagon Devices Inc. Pullman, USA). The concentrations of calcium $(\mathrm{Ca})$, magnesium $(\mathrm{Mg})$, and potassium $(\mathrm{K})$ were determined using atomic absorption spectroscopy in the flame (F-AAS) (SpectrAA-800, Varian, USA) following prior mineralization with nitric acid (Rybicka and Gliszczyńska-Świgło 2017). The content of P was determined spectrophotometrically at $640 \mathrm{~nm}$ according to Szydłowska-Czerniak and Szłyk (2003). The content of minerals was expressed in mg per $100 \mathrm{~g}$ of sample.

\subsection{Physical properties of extrudates}

The expansion ratio (ER) was determined as the ratio of the extrudate diameter to the nozzle diameter (Makowska et al. 
2018). Water Absorption Index (WAI) and Water Solubility Index (WSI) were determined according to the method described by Singha et al. (2018). The bulk density (BD) of the extrudates was calculated as a ratio of extrudate weight to its volume (Ali et al. 1996). The colour of obtained extrudates was measured using a Chroma Meter CR-410 colour metre (Konica Minolta Sensing Inc., Tokyo, Japan) in CIE L*a*b* system in terms of lightness $\left(\mathrm{L}^{*}\right)$ and colour $\left(\mathrm{a}^{*}\right.$-redness; $\mathrm{b}^{*}$-yellowness) (Kowalczewski et al. 2015). The colour measurement was conducted in ten replicates. Moreover, the total colour difference $(\Delta \mathrm{E})$ was calculated using the following formula (Pauter et al. 2018):

$\Delta E=\sqrt{\Delta L^{* 2}+\Delta a^{* 2}+\Delta b^{* 2}}$

\subsection{Calculation of PRAL}

The potential renal acid load (PRAL) of obtained extrudates was calculated following the procedure of Remer et al. (2003) based on average content of PRAL-determining factors, i.e. protein, $\mathrm{Ca}, \mathrm{Mg}$, phosphorus $(\mathrm{P})$ and $\mathrm{K}$ contents, by the following formula:

$$
\begin{aligned}
\operatorname{PRAL}(\mathrm{mEq} / 100 \mathrm{~g})= & 0.49 \times \text { protein }(\mathrm{g} / 100 \mathrm{~g})+0.037 \\
& \times \mathrm{P}(\mathrm{mg} / 100 \mathrm{~g})-0.021 \\
& \times \mathrm{K}(\mathrm{mg} / 100 \mathrm{~g})-0.026 \\
& \times \mathrm{Mg}(\mathrm{mg} / 100 \mathrm{~g})-0.013 \\
& \times \mathrm{Ca}(\mathrm{mg} / 100 \mathrm{~g}) .
\end{aligned}
$$

\subsection{Texture analysis}

Texture was analysed following the procedure of Makowska et al. (2018) using a TA.XTplus texture analyser (Stable Micro System Co. Ltd., England) equipped with a $50 \mathrm{~kg}$ load cell and a Warner-Bratzler blade to cut across the diameter of the sample. The test speed was $2.0 \mathrm{~mm} / \mathrm{s}$. Maximum force to cut the sample was recorded as the hardness $[\mathrm{N}]$. Additionally, the Breaking Force Index (BFI) $\left[\mathrm{N} \mathrm{mm}{ }^{-1}\right]$ was calculated as a ratio of the maximum force required to cut the sample into two pieces to diameter of analysed sample (Chaiyakul et al. 2009). The experiment was conducted in fifteen replicates.

\subsection{Acoustic emission properties of extrudates}

The analysis of the acoustic emission properties of the obtained extrudates was carried out using the analyser of the acoustic properties of food products (COBRABiD Ltd. Poland) (Poliszko et al. 2017). The analysis was performed in ten replicates. Mechanical biting simulator applied was equipped with an accelerometric sensor of acoustic emission, operating in the frequency range from $3 \mathrm{~Hz}$ to $20 \mathrm{kHz}$. The emission spectra in this frequency range were acquired with the use of a one-third-octave band-pass filter. The following audio-sensory properties of the products were evaluated: total loudness $(N)$ and volume values of individual audial features: crackliness $(A)$, crispness $(I)$ and crunchiness $(U)$. The values were expressed on a 10 point scale calibrated on the basis of sensory evaluation of a reference product (Bake rolls-a snack product in a form of thinly sliced rounds of twice-baked bread). The values of the measurements were determined based on the following equation:

$N_{x}=N_{R} \cdot 10^{\frac{\left(L_{x}-L_{s}\right) \cdot x_{x}}{10}}$,

where $N_{x}$ is the volume of the sensed characteristic e.g.: A, $I, U$ and $N ; N_{R}$ is the volume of the sensory characteristics of the reference product assessed (Bake rolls); $L_{x}$ is the measured integral acoustic emission level of the test sample; $L_{s}$ is the measured integral acoustic emission level of the standard; $\alpha_{x}$ is the calibration factors of the instrumental-sensory relationships for dry products (Poliszko et al. 2014).

\subsection{Consumer study}

Consumer rating was evaluated according to the 9-point hedonic line scale (ranging from 1-dislike very much to 9-like very much) (Villanueva et al. 2000). Fifty-five untrained panellists, between the age of twenty and sixtyfive, were asked to evaluate the appearance, colour, crispiness, taste, texture and overall acceptability of manufactured extrudates. The information about gender and consumers ages is presented in Table 1 .

\subsection{Statistical analysis}

All measurements were repeated in triplicate, unless otherwise stated. One-way analysis of variance (ANOVA) was carried out independently for each dependent variable. Post-hoc Tukey HSD multiple comparison test was used to identify statistically homogeneous subsets at $\alpha=0.05$. Statistical analysis was performed with Statistica 13 software (Dell Software Inc., USA).

Table 1 Age characteristics of respondents

\begin{tabular}{llll}
\hline Age $($ years $)$ & Total $(\mathrm{n}=55)$ & Women $(\mathrm{n}=35)$ & Men $(\mathrm{n}=20)$ \\
\hline $20-29$ & 20 & 11 & 9 \\
$30-39$ & 19 & 12 & 7 \\
$40-49$ & 11 & 8 & 3 \\
$\geq 50$ & 5 & 4 & 1 \\
\hline
\end{tabular}




\section{Results and discussion}

\subsection{Physical characteristics of extrudates}

The addition of PF altered the physical properties of the analysed extrudates (Table 2). Expansion ratio (ER) is one of the quality indicators of extrudates. The higher the ER of an extrudate is, the better it is perceived by a consumer. A decrease in the ER was observed with the increase of PF addition. A reverse relationship was noted for the bulk density (BD) of extrudates. In this case, the addition of PF resulted in an increase in BD. The expansion ratio and the bulk density of extrudates is strongly associated with the chemical composition of raw materials used for the production of extrudates. For example, high content of dietary fibre in the extruded raw material causes a reduction of the expansion ratio and an increase of the density of the obtained products (Robin et al. 2011). It should be noted, that variants with 6 and $8 \%$ PF were initially also prepared but they have shown unacceptable ER and taste (data not shown).

The addition of PF also caused changes of WAI and WSI values. These parameters correspond to the degree of starch gelatinization resulting from extrusion. The WAI value increased from $627.45 \mathrm{~g} / \mathrm{g}$ for $\mathrm{C}$ to $698.88 \mathrm{~g} / \mathrm{g}$ for PFE4, while the WSI value decreased from 36.78 to 30.54 , respectively (Table 2). The WAI value depends on the temperature of the extrusion process. With increasing temperature, the starch gelation process is more effective and less dextrinized starch is formed. Also the WSI value depends on the parameters of the extrusion process, such as intensive mechanical shear, high pressure and temperature (Gumul et al. 2011; Makowska et al. 2018; Pęksa et al. 2016). As all the extrudates were produced with the same parameters of the extrusion process (Ding et al. 2005; Makowska et al. 2018), the changes observed to WAI and WSI values result strictly from the modification of the raw materials. A high value of WSI is not desirable from nutritional point of view as it indicates fast digestive process and intestinal absorption (Altan 2009). No effect of PF addition on water activity was observed, which was
$0.238 \pm 0.016,0.239 \pm 0.011$ and $0.232 \pm 0.025$ for $\mathrm{C}$, PFE2 and PFE4, respectively.

The colour of food products is one of the basic parameters affecting consumer acceptance. The PF addition influenced the colour of the products (Table 3). With increasing amounts of PF addition the value of lightness $\left(\mathrm{L}^{*}\right)$ decreased, while the green/red $\left(\mathrm{a}^{*}\right)$ colour balance was shifted towards red. The addition did not change the yellow/blue colour balance ( $\left.b^{*}\right)$. Nevertheless, the overall colour difference $(\Delta \mathrm{E})$ value indicates a significant effect of $\mathrm{PF}$ addition on the colour of the extrudates. A colour difference value $(\Delta \mathrm{E})$ above 2 can be noticed by an inexperienced observer (Mokrzycki and Tatol 2011). The total colour differences in the analysed extrudates were 2.77 for PFE2 and 6.40 for PFE4, which indicates that colour changes can be noticed even by an inexperienced observer.

Pumpkin and pumpkin-based products, such as flour, are an important source of many nutrients, including minerals (El-Adawy and Taha 2001; National Nutrient Database for Standard Reference 2016; Zdrojewicz et. al. 2016). The pumpkin flour used in the present study was also characterised by a high content of macroelements. The content of Ca was $187 \pm 17 \mathrm{mg}$ in $100 \mathrm{~g}$, of $\mathrm{K}$ was $3034 \pm 103 \mathrm{mg}$ in $100 \mathrm{~g}$, of $\mathrm{Mg}$ was $1070 \pm 132 \mathrm{mg}$ in $100 \mathrm{~g}$ and of $\mathrm{P}$ was $393 \pm 22 \mathrm{mg}$ in $100 \mathrm{~g}$. For reference, the content of the mentioned macroelements in $100 \mathrm{~g}$ of plain and wholemeal wheat flour is approx. 20 and $35 \mathrm{mg}$ of $\mathrm{Ca}, 100 \mathrm{mg}$ and $350 \mathrm{mg}$ of $\mathrm{K}, 10$ and $100 \mathrm{mg}$ of $\mathrm{Mg}$, and 70 and $300 \mathrm{mg}$ of $\mathrm{P}$, respectively (National Nutrient Database for Standard Reference 2016). The content of $\mathrm{Ca}, \mathrm{K}, \mathrm{Mg}$ and $\mathrm{P}$ in analysed extrudates is presented in Table 4 . As expected, a statistically significant increase $(p<0.05)$ in the concentration of these elements were observed. The elemental profile of pumpkin flour makes it a valuable ingredient for improving the nutritional quality of corn extrudates.

\subsection{The effect of PF addition on potential renal acid load}

Diet determines the amount of acidifying agents supplied to the organism that have to be excreted through the kidneys to maintain a proper acid-base balance. One of the
Table 2 Physical characteristics and potential renal acid load of extrudates $(\mathrm{n}=3)$

\begin{tabular}{lllll}
\hline Sample & ER $(-)$ & BD $\left(\mathrm{g} / \mathrm{cm}^{3}\right)$ & WAI $(\mathrm{g} / \mathrm{g})$ & WSI $(\%)$ \\
\hline C & $4.27 \pm 0.17^{\mathrm{a}}$ & $0.030 \pm 0.001^{\mathrm{c}}$ & $627.45 \pm 16.60^{\mathrm{c}}$ & $36.78 \pm 4.84^{\mathrm{a}}$ \\
PFE2 & $4.06 \pm 0.09^{\mathrm{ab}}$ & $0.040 \pm 0.002^{\mathrm{b}}$ & $670.93 \pm 6.48^{\mathrm{b}}$ & $34.67 \pm 1.09^{\mathrm{ab}}$ \\
PFE4 & $3.76 \pm 0.12^{\mathrm{b}}$ & $0.045 \pm 0.001^{\mathrm{a}}$ & $698.88 \pm 24.80^{\mathrm{a}}$ & $30.54 \pm 0.48^{\mathrm{b}}$ \\
\hline
\end{tabular}

Mean \pm Standard Deviation values with different letters $(\mathrm{a}-\mathrm{c})$ in the columns are significantly different $(\mathrm{p} \leq 0.05)$

$C$ control extrudates, $P F E 2$, PFE4 extrudates with $2 \%$ and $4 \%$ pumpkin flour, respectively, ER expansion ratio, $B D$ bulk density, $W A I$ water absorption index, $W S I$ water solubility index 
Table 3 Colour parameters of obtained extrudates $(n=10)$

\begin{tabular}{lllll}
\hline Sample & L $^{*}$ & $\mathrm{a}^{*}$ & $\mathrm{~b}^{*}$ & $\Delta \mathrm{E}$ \\
\hline $\mathrm{C}$ & $81.21 \pm 0.25^{\mathrm{a}}$ & $1.21 \pm 0.01^{\mathrm{c}}$ & $33.20 \pm 0.50^{\mathrm{a}}$ & - \\
PFE2 & $79.03 \pm 0.45^{\mathrm{b}}$ & $2.82 \pm 0.24^{\mathrm{b}}$ & $33.80 \pm 1.94^{\mathrm{a}}$ & 2.77 \\
PFE4 & $75.73 \pm 0.04^{\mathrm{c}}$ & $4.50 \pm 0.01^{\mathrm{a}}$ & $33.60 \pm 0.50^{\mathrm{a}}$ & 6.40 \\
\hline
\end{tabular}

Mean \pm Standard Deviation values with different letters $(a-c)$ in the columns are significantly different $(\mathrm{p} \leq 0.05)$

$C$ control extrudates, PFE2, PFE4 extrudates with $2 \%$ and $4 \%$ pumpkin flour, respectively, $L^{*}$ lightness, $a^{*}$ redness, $b^{*}$ yellowness, $\Delta E$ total colour difference

methods of estimating the acid load of food is based on calculating PRAL which allows an estimation of the net excretion of endogenous acid for a given amount of food intake per day. The calculation model takes into account the amount of ingested minerals and protein, different levels of intestinal absorption of specific minerals, and the metabolism of sulphur (Remer and Manz 1995; Remer et al. 2003; Scialla and Anderson 2013). Generally, foods can be categorised on the basis of the PRAL in two groups: deacidifying and acidifying. Products with a low phosphorus content, fruit and vegetables and products containing them have the ability to deacidify the body, thus the PRAL indicator takes negative values. Meat and dairy products have relatively high acid loads and hence positive PRAL indicator values (Schwalfenberg 2012). The calculated PRAL value of pumpkin flour was - 50.04, which indicates a strong alkalizing effect of this raw material. Cereals and cereal products are considered acidifying products (Remer et al. 2003), however, the PRAL value for $\mathrm{C}$ was -9.75 (Table 4). The use of the PF additive in the recipe resulted in a decrease of this parameter by 4 points for PFE2 and by almost 6 points for PFE4. Published data also indicate that pumpkin and pumpkin flour, due to high fibre content, as well as other biologically active compounds, such as $\beta$-carotene, vitamin $\mathrm{A}$, tocopherol and vitamins (Nawirska et al. 2009; Wang et al. 2002; Zhang et al. 2000) can help regulate insulin levels in serum, reduce blood glucose level (Quanhong et al. 2005). Furthermore, it can provide protection against diseases such as diabetes, cardiovascular disease, constipation and colon cancer (Anderson et al. 1994; Kwon et al. 2007; Zdrojewicz et al. 2016). Thus, pumpkin flour can be a valuable raw material for pro-health food products.

\subsection{Textural and acoustic properties}

The textural properties of extrudates with PF were determined by measuring the hardness and calculating the breaking force index. The addition of $4 \% \mathrm{PF}$ resulted in decreased hardness and BFI compared to control (Table 5). However, no significant changes were observed in the value of the analysed parameters for PFE2 extrudates. The use of various additives for the production of corn extrudates may result in a number of changes in textural properties, usually increasing their hardness. For example, Li et al. (2005) showed an increase in the hardness of corn extrudates with the addition of soy flour. Also other protein-rich additives (Anton et al. 2009; Cheng et al. 2007; Lazou and Krokida 2010), as well as fibre-rich additives (Ainsworth et al. 2007; Altan et al. 2008) may increase the hardness of enriched extrudates. However, the use of vegetable additives may cause changes in the formation of a porous structure of extrudates, and consequently, reduce the hardness (Dehghan-Shoar et al. 2010). All these changes have potential effects on the audio-emission properties of extrudates.

In general, consumer acceptance of food that shows acoustic activity depends strongly on the identification of a specific timbre of sound perceived during consumption. The spectrum of emitted sounds is decisive for differentiation of these timbres (Demattè et al. 2014; Duizer 2001; Spence 2015). With this in mind, the spectra of acoustic emission of the extrudates were analysed. In Fig. 1, differential spectra obtained through subtraction of the signal volume of the sample from the signal volume of the reference tested alternately (first the reference sample and after that the test sample in the cycles, repeated 10 times) in the same conditions. This way of presentation makes the results free from any artefacts of instrumental origin.

The spectra off all the samples showed noticeable similarity indicating certain analogy of the structural organisation of the extrudates, from which the acoustic

Table 4 Chemical composition of obtained extrudates $(n=3)$

\begin{tabular}{llllllll}
\hline Sample & $\begin{array}{l}\text { Protein content } \\
(\%)\end{array}$ & Ash content $(\%)$ & $\mathrm{Mg}(\mathrm{mg} / 100 \mathrm{~g})$ & $\mathrm{P}(\mathrm{mg} / 100 \mathrm{~g})$ & $\mathrm{K}(\mathrm{mg} / 100 \mathrm{~g})$ & $\begin{array}{l}\text { Ca }(\mathrm{mg} / \\
100 \mathrm{~g})\end{array}$ & $\begin{array}{l}\text { PRAL }(\mathrm{mEq} / \\
100 \mathrm{~g})\end{array}$ \\
\hline $\mathrm{C}$ & $9.04 \pm 0.07^{\mathrm{a}}$ & $0.429 \pm 0.063^{\mathrm{b}}$ & $182.99 \pm 5.96^{\mathrm{b}}$ & $576.25 \pm 6.41^{\mathrm{a}}$ & $1446.90 \pm 11.12^{\mathrm{c}}$ & $27.28 \pm 0.63^{\mathrm{c}}$ & -9.75 \\
$\mathrm{PFE} 2$ & $8.81 \pm 0.14^{\mathrm{b}}$ & $0.440 \pm 0.072^{\mathrm{ab}}$ & $196.17 \pm 2.23^{\mathrm{ab}}$ & $552.98 \pm 4.43^{\mathrm{b}}$ & $1574.95 \pm 10.51^{\mathrm{b}}$ & $31.45 \pm 1.11^{\mathrm{b}}$ & -13.76 \\
$\mathrm{PFE} 4$ & $8.53 \pm 0.15^{\mathrm{c}}$ & $0.529 \pm 0.088^{\mathrm{a}}$ & $211.66 \pm 3.21^{\mathrm{a}}$ & $539.68 \pm 6.26^{\mathrm{c}}$ & $1615.69 \pm 12.13^{\mathrm{a}}$ & $34.57 \pm 1.21^{\mathrm{a}}$ & -15.59 \\
\hline
\end{tabular}

Mean \pm Standard Deviation values with different letters $(\mathrm{a}-\mathrm{c})$ in the columns are significantly different $(\mathrm{p} \leq 0.05)$

$C$ control extrudates, PFE2, PFE4 extrudates with $2 \%$ and $4 \%$ pumpkin flour, respectively 
Table 5 The mechanical properties of extrudates $(n=15)$

\begin{tabular}{lll}
\hline Sample & Hardness $(\mathrm{N})$ & Breaking force index $(\mathrm{N} / \mathrm{mm})$ \\
\hline $\mathrm{C}$ & $9.01 \pm 0.49^{\mathrm{a}}$ & $0.62 \pm 0.09^{\mathrm{a}}$ \\
PFE2 & $8.80 \pm 0.85^{\mathrm{a}}$ & $0.60 \pm 0.06^{\mathrm{a}}$ \\
PFE4 & $6.36 \pm 0.32^{\mathrm{b}}$ & $0.48 \pm 0.06^{\mathrm{b}}$
\end{tabular}

Mean \pm Standard Deviation values with different letters $(a-b)$ in the columns are significantly different $(\mathrm{p} \leq 0.05)$

$C$ control extrudates, PFE2, PFE4 extrudates with $2 \%$ and $4 \%$ pumpkin flour, respectively

phenomena result. At the current state of the art, there is a lack of data that would facilitate interpretation of such observations. Hypothetically, it can be assumed that, the acoustic emission in the high frequency range is associated with longitudinal vibrations during disruption of the cell walls and destruction of starch matrix, while the emission in the low frequency range results from brake down and the crosswise vibrations of the walls. Under this assumption, the decreased volume of emission in the case of PFE4 (Fig. 1) can be attributed to a plasticizing effect of the additive. The spectrum generated by PFE2 did not indicate such effects. Contrary to PFE4, some regions of this spectrum suggest an opposite effect of the additive. It should be noted that correlating the spectra of acoustic emission with the perception of a consumer must take into account the alteration of the signal by the acoustic properties of human head: especially the resonance of the skull, mouth and the outer ear canal. The method utilised in this study, based on the calibration of the instrument according to sensory perception, seems to be the most effective (Poliszko et al. 2017).

Audio-sensory analysis distinguishes three basic sound features of a food product: crackliness (A), crispness (I) and crunchiness (U) (Chauvin et al. 2008; Stangierski et al. 2016). Similarly to the RGB system used in colorimetry, the quantitative description of a product-specific
Table 6 Characteristics of audio-emission properties $(\mathrm{n}=10)$

\begin{tabular}{lllll}
\hline Sample & N & A & I & U \\
\hline C & $6.17 \pm 0.42^{\mathrm{a}}$ & $6.04 \pm 0.49^{\mathrm{a}}$ & $6.45 \pm 0.39^{\mathrm{a}}$ & $5.93 \pm 0.38^{\mathrm{a}}$ \\
PFE2 & $6.07 \pm 0.32^{\mathrm{a}}$ & $5.94 \pm 0.38^{\mathrm{a}}$ & $6.34 \pm 0.29^{\mathrm{a}}$ & $5.85 \pm 0.30^{\mathrm{a}}$ \\
PFE4 & $4.80 \pm 0.42^{\mathrm{b}}$ & $4.36 \pm 0.50^{\mathrm{b}}$ & $5.33 \pm 0.47^{\mathrm{b}}$ & $4.58 \pm 0.41^{\mathrm{b}}$ \\
\hline
\end{tabular}

Mean \pm Standard Deviation values with different letters $(a-b)$ in the columns are significantly different $(\mathrm{p} \leq 0.05)$

$C$ control extrudates, PFE2, PFE4 extrudates with $2 \%$ and $4 \%$ pumpkin flour, respectively, $N$ total loudness, $A$ crackliness, $I$ crispness, $U$ crunchiness

timbre can be presented in an AIU system, for example, in a 10-degree scale based on sound perception. Moreover, such numerical description can be complemented with total loudness $(\mathrm{N})$ value, a parameter analogous to lightness $\mathrm{L}$ in the LAB system used in colorimetry.

The parameters of NAIU ( $\mathrm{N}$-loudness, $\mathrm{A}$-crackliness, I-crispiness, U-crunchiness) system describe the timbre of a product in an unambiguous manner. The system can be used for monitoring changes resulting from the alteration of composition or storage conditions. Moreover, the system could become a method for identification and differentiation of products based on their acoustic emission proprieties or quality evaluation. The results of the analysis (Table 6) show that no significant changes to the acoustic properties of the extrudates were triggered by a $2 \%$ pumpkin flour addition (PFE2), as was also the case in texture analyses. A decrease of the total volume and the specific acoustic features were observed in PFE4.

\subsection{Consumer attractiveness of enriched extrudates}

Introducing additives into the recipe of food products is not a simple task. On the one hand, additives can increase the nutritional value of the developed product, on the other,
Fig. 1 Differential spectra of the acoustic emission signal of the extrudates relative to the standard signal of Bake rolls samples

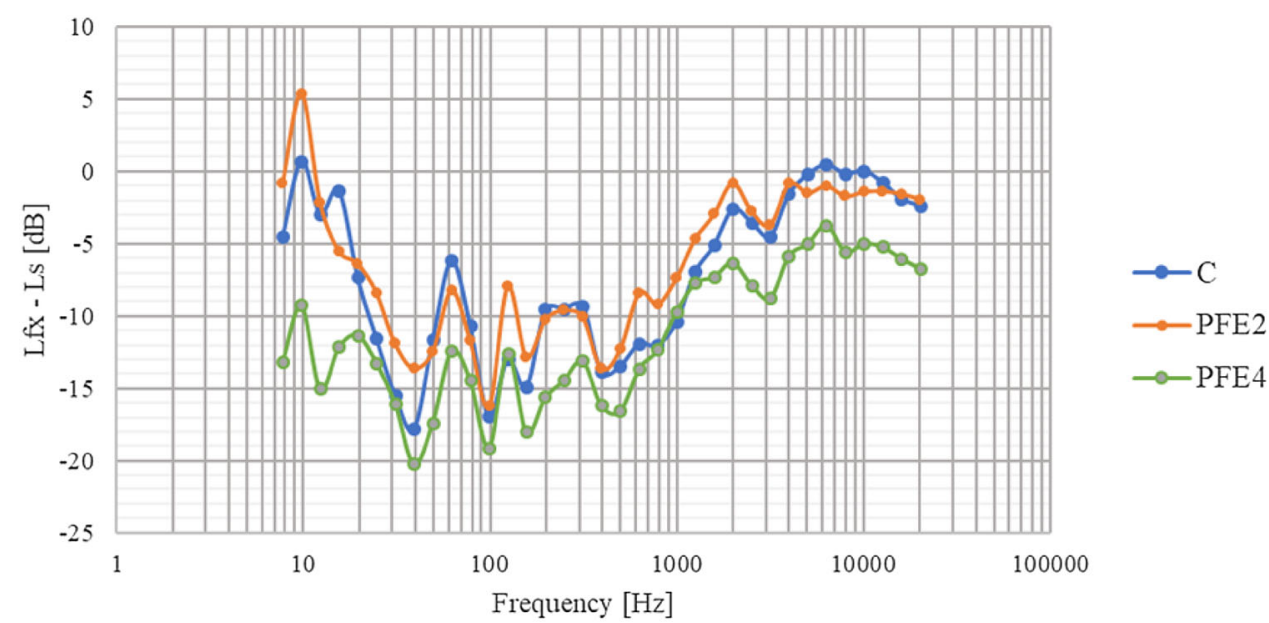




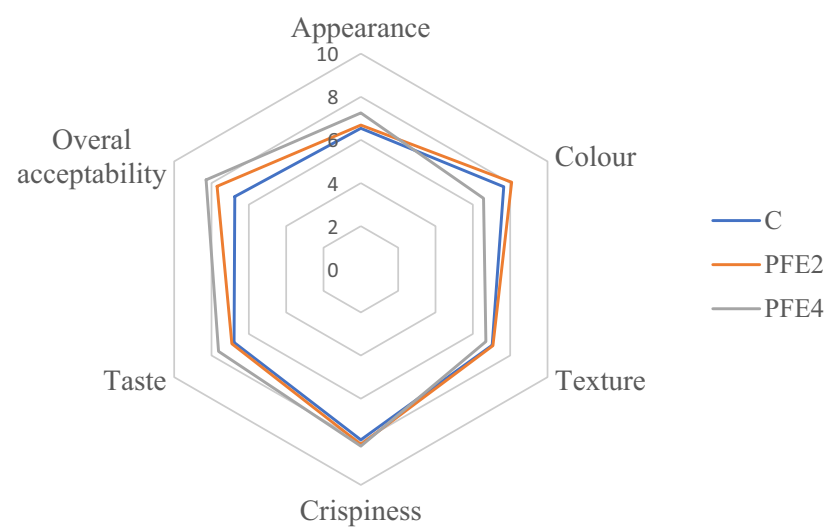

Fig. 2 The results of the consumer study $(\mathrm{n}=55) . C$ control extrudates, PFE2, PFE4 extrudates with $2 \%$ and $4 \%$ pumpkin flour, respectively

cause change to various properties in relation to the conventional product. Changes in physicochemical and mechanical properties, including acoustic properties, may lead to changes in consumer perception of the obtained product (Sun-Waterhouse and Wadhwa 2013). The results of the consumer study (Fig. 2) show that extrudates with addition of PF found higher consumer acceptance than the control snacks. Despite the instrumentally determined textural changes no difference in texture and crispiness was noticed by consumers between PFE2, PFE4 and C. Also Pęksa et al. (2016) report that the use of pumpkin additive lowers the marks awarded to the texture of products enriched with it. The participants of consumer study pointed out that extrudates with $2 \%$ addition of $\mathrm{PF}$ had a more attractive colour than $\mathrm{C}$, but increasing the $\mathrm{PF}$ additive resulted in a decreased colour rating. Published literature data confirm that a small addition of pumpkin can have a positive impact on the assessment of enriched products by consumers, but the more additive the less attractive products become (Kampuse et al. 2015; Mirhosseini et al. 2015). Nevertheless, the overall acceptability scores achieved by the PFE2 and PFE4 were higher than C. Thus, it is possible that among consumers paying attention to health-promoting food products, extrudates with PF addition would find better acceptance than the standard product.

\section{Conclusions}

In this paper, the impact of introducing pumpkin flour to corn grit-based extrudates was analysed. It was found that the PF addition caused a reduction in extrudate expansion as well as water solubility index but caused an increase in bulk density and water absorption index. Changes of colour were observed as well. The addition of PF caused a reduction in lightness of extrudates and a shift in colour balance toward green. In addition, the introduction of PF caused a number of changes in the textural characteristics of the products obtained. The hardness and breaking force index were significantly reduced as the amount of $\mathrm{PF}$ increased. Audio-emission parameters (total loudness, crackliness, crispness and crunchiness) were also affected, with a decrease in volume of all these features observed at higher level of PF. Nevertheless, taking into account the slight change in texture and sensory acceptance, pumpkin flour can be used in production of corn snacks with lower acidity.

Funding The authors received no financial support for the research, authorship, and/or publication of this article.

Conflict of interest The authors declare that they have no conflict of interest.

Open Access This article is distributed under the terms of the Creative Commons Attribution 4.0 International License (http://creative commons.org/licenses/by/4.0/), which permits unrestricted use, distribution, and reproduction in any medium, provided you give appropriate credit to the original author(s) and the source, provide a link to the Creative Commons license, and indicate if changes were made.

\section{References}

AACC International (1999) Approved methods of analysis, 11th Ed. Method 08-01.01. Ash - basic method. Approved November 3, 1999. AACC International, St. Paul, MN, U.S.A. https://doi.org/ 10.1094/AACCIntMethod-08-01.01

Ainsworth P, Ibanoglu S, Plunkett A, Ibanoglu E, Stojceska V (2007) Effect of brewers spent grain addition and screw speed on the selected physical and nutritional properties of an extruded snack. J Food Eng 81:209-702. https://doi.org/10.1016/j.jfoodeng.2007. 01.004

Akwaowo EU, Ndon BA, Etuk EU (2000) Minerals and antinutrients in fluted pumpkin (Telfairia occidentalis Hook $f$.). Food Chem 70(2):235-240. https://doi.org/10.1016/S0308-8146(99)00207-1

Ali Y, Hanna MA, Chinnaswamy R (1996) Expansion characteristics of extruded corn grits. Lebensm-Wiss Technol 29:702-707

Altan A, McCarthy KL, Maskan M (2008) Evaluation of snack foods from barley-tomato pomace blends by extrusion processing. J Food Eng 84(2):231-242. https://doi.org/10.1016/j.jfoodeng. 2007.05.014

Altan A, McCarthy KL, Maskan M (2009) Effect of extrusion cooking on functional properties and in vitro starch digestibility of barley-based extrudates from fruit and vegetable by-products. J Food Sci 74:E77-E86. https://doi.org/10.1111/j.1750-3841. 2009.01051.x

Anderson JW, Smith BM, Guftanson NJ (1994) Health benefits and practical aspects of high-fiber diet. Am J Clin Nutr 59:1242-1247

Anton AA, Gary Fulcher R, Arntfield SD (2009) Physical and nutritional impact of fortification of corn starch-based extruded snacks with common bean (Phaseolus vulgaris L.) flour: effects of bean addition and extrusion cooking. Food Chem 
113(4):989-996. https://doi.org/10.1016/j.foodchem.2008.08. 050

Betoret E, Betoret N, Vidal D, Fito P (2011) Functional foods development: trends and technologies. Trends Food Sci Technol 22:498-508. https://doi.org/10.1016/j.tifs.2011.05.004

Caili F, Huan S, Quanhong L (2006) A review on pharmacological activities and utilization technologies of Pumpkin. Plant Foods Hum Nutr 61(2):70-77. https://doi.org/10.1007/s11130-0060016-6

Cerniauskiene J, Kulaitiene J, Danilcenko H, Jariene E, Jukneviciene E (2014) Pumpkin fruit flour as a source for food enrichment in dietary fiber. Not Bot Horti Agrobo 42(1):19-23 https://doi.org/ 10.15835/nbha4219352

Chaiyakul S, Jangchud K, Jangchud A, Wuttijumnong P, Winger R (2009) Effect of extrusion conditions on physical and chemical properties of high protein glutinous rice-based snack. LWT-Food Sci Technol 42:781-787. https://doi.org/10.1016/j.lwt.2008.09. 011

Chauvin MA, Younce F, Ross C, Swanson B (2008) Standard scales for crispness, crackliness and crunchiness in dry and wet foods: relationship with acoustical determinations. J Text Stud 39:345-368. https://doi.org/10.1111/j.1745-4603.2008.00147.x

Cheng EM, Alavi S, Pearson T, Agbisit R (2007) Mechanicalacoustic and sensory evaluations of corn starch-whey protein isolate extrudates. J Texture Stud 38(4):473-498. https://doi.org/ 10.1111/j.1745-4603.2007.00109.x

Dehghan-Shoar Z, Hardacre AK, Brennan CS (2010) The physicochemical characteristics of extruded snacks enriched with tomato lycopene. Food Chem 123(4):1117-1122. https://doi.org/10. 1016/j.foodchem.2010.05.071

Demattè ML, Pojer N, Endrizzi I, Corollaro ML, Betta E, Aprea E, Charles M, Biasioli F, Zampini M, Gasperi F (2014) Effects of the sound of the bite on apple perceived crispness and hardness. Food Qual Prefer 38:58-64. https://doi.org/10.1016/j.foodqual. 2014.05.009

Ding QB, Ainsworth P, Tucker G, Marson H (2005) The effect of extrusion conditions on the physicochemical properties and sensory characteristics of rice-based expanded snacks. J Food Eng 66(3):283-289. https://doi.org/10.1016/j.jfoodeng.2004.03. 019

Duizer L (2001) A review of acoustic research for studying the sensory perception of crisp, crunchy and crackly textures. Trends Food Sci Technol 12(1):17-24. https://doi.org/10.1016/S09242244(01)00050-4

El-Adawy TA, Taha KM (2001) Characteristics and composition of different seed oils and flours. Food Chem 74(1):47-54. https:// doi.org/10.1016/S0308-8146(00)00337-X

Goetzke B, Nitzko S, Spiller A (2014) Consumption of organic and functional food. A matter of well-being and health? Appetite 77:94-103. https://doi.org/10.1016/j.appet.2014.02.012

Gumul D, Ziobro R, Zięba T, Rój E (2011) The influence of addition of defatted blackcurrant seeds on pro-health constituents and texture of cereal extrudates. J Food Qual 34:395-402. https://doi. org/10.1111/j.1745-4557.2011.00418.x

Guy RCE (2001) Raw materials for extrusion cooking. In: Guy R (ed) Extrusion cooking. Woodhead Publishing, London, pp 5-28. https://doi.org/10.1533/9781855736313.1.5

ISO 18787:2017 (2017) Foodstuffs - determination of water activity. In: ISO Standards Handbook. International Organization for Standardization. https://www.iso.org/obp/ui/\#iso:std:iso:18787: ed-1:v1:en

Kampuse S, Ozola L, Straumite E, Galoburda R (2015) Quality parameters of wheat bread enriched with pumpkin (Cucurbita moschata) by-products. Acta Universitatis Cibiniensis. Ser E Food Technol 19(2):3-14
Kowalczewski P, Lewandowicz G, Makowska S, Knoll I, Błaszczak W, Białas W, Kubiak P (2015) Pasta fortified with potato juice: structure, quality, and consumer acceptance. J Food Sci 80(6):S1377-S1382. https://doi.org/10.1111/1750-3841.12906

Kwon Y-I, Apostolidis E, Kim YC, Shetty KK (2007) Health benefits of traditional corn, beans, and pumpkin: in vitro studies for hyperglycemia and hypertension management. J Med Food 10(2):266-275. https://doi.org/10.1089/jmf.2006.234

Lazou A, Krokida M (2010) Structural and textural characterization of corn-lentil extruded snacks. J Food Eng 100:392-408. https:// doi.org/10.1016/j.jfoodeng.2010.04.024

Lazou A, Krokida M, Tzia C (2010) Sensory properties and acceptability of corn and lentil extruded puffs. J Sens Stud 25:838-860. https://doi.org/10.1111/j.1745-459X.2010.00308.x

Li S-Q, Zhang HQ, Jin ZT, Hsieh F-H (2005) Textural modification of soya bean/corn extrudates as affected by moisture content, screw speed and soya bean concentration. Int $\mathrm{J}$ Food Sci Tech 40:731-741. https://doi.org/10.1111/j.1365-2621.2005.00993.x

Makowska A, Mildner-Szkudlarz S, Obuchowski W (2013) Effect of brewer's spent grain addition on properties of corn extrudates with an increased dietary fibre content. Pol J Food Nutr Sci 63(1):19-24. https://doi.org/10.2478/v10222-012-0061-9

Makowska A, Baranowska HM, Michniewicz J, Chudy S, Kowalczewski PŁ (2017) Triticale extrudates - changes of macrostructure, mechanical properties and molecular water dynamics during hydration. J Cereal Sci 74:250-255. https://doi.org/10. 1016/j.jcs.2017.03.002

Makowska A, Zielińska-Dawidziak M, Niedzielski P, Michalak M (2018) Effect of extrusion conditions on iron stability and physical and textural properties of corn snacks enriched with soybean ferritin. Int J Food Sci Technol 53(2):296-303. https:// doi.org/10.1111/ijfs. 13585

Mirhosseini H, Abdul Tashid NF, Tabatabaee Amid B, Cheong KW, Kazemi M, Zulkurnain M (2015) Effect of partial replacement of corn flour with durian seed flour and pumpkin flour on cooking yield, texture properties, and sensory attributes of gluten free pasta. LWT-Food Sci Technol 63(1):184-190. https://doi.org/10. 1016/j.lwt.2015.03.078

Mokrzycki WS, Tatol M (2011) Color difference $\Delta \mathrm{E}$ : a survey. Mach Gr Vis 20(4):383-411

National Nutrient Database for Standard Reference (2016) United States Department of Agriculture, Agricultural Research Service, Release 27, https://ndb.nal.usda.gov/ndb/nutrients/index. Accessed 27 July 2018

Nawirska A, Figiel A, Kucharska AZ, Sokoł-Łetowska A, Biesia A (2009) Drying kinetics and quality parameters of pumpkin slices dehydrated using different methods. J Food Eng 94:14-20

Niewczas J, Mietek M (2010) Content of mineral components in the fruit of five varieties of winter squash (Cucurbita maxima). Zywn-Nauk Technol Ja 5(72):77-84

Oniszczuk A, Wójtowicz A, Oniszczuk T, Olech M, Nowak R, Wojtunik K, Klimek M, Krawczyk W, Hajnos M (2015) Extruded corn gruels containing linden flowers: quantitation of phenolic compounds and selected quality characteristics. Open Chem 13(1):1209-1217. https://doi.org/10.1515/chem-20150138

Pauter P, Różańska M, Wiza P, Dworczak S, Grobelna N, Sarbak P, Kowalczewski PŁ (2018) Effects of the replacement of wheat flour with cricket powder on the characteristics of muffins. Acta Sci Pol Technol Aliment 17(3):227-233 https://doi.org/10. 17306/J.AFS.2018.0570

Pęksa A, Kita A, Carbonell-Barrachina AA, Miedzianka J, KolniakOstek J, Tajner-Czopek A, Rytel E, Siwek A, Miarka D, Drożdż W (2016) Sensory attributes and physicochemical features of corn snacks as affected by different flour types and extrusion 
conditions. LWT Food Sci Technol 72:26-36. https://doi.org/10. 1016/j.lwt.2016.04.034

Pęksa A, Kita A, Jariene E, Danilcenko H, Gryszkin A, Figiel A, Kulaitiene J, Cerniauskiene J, Aniolowska M (2016) Amino acid improving and physical qualities of extruded corn snacks using flours made from jerusalem artichoke (Helianthus tuberosus), amaranth (Amaranthus cruentus L.) and pumpkin (Cucurbita maxima L.) J Food Qual 39(6):580-589

Peressini D, Foschia M, Tubaro F, Sensidori A (2015) Impact of soluble dietary fibre on the characteristics of extruded snacks. Food Hydrocoll 43:73-81. https://doi.org/10.1016/j.foodhyd. 2014.04.036

PN-EN ISO 20483:2014-02 Cereals and pulses - Determination of the nitrogen content and calculation of the crude protein content Kjeldahl method

Poliszko S, Mizgalski I, Murawka S, Szczepka M, Taterczyński W (2017) Analyzer of food products acoustic properties. PL Patent 225545

Poliszko S, Baranowski P, Matusiak G, Mizgalski I, Murawka S, Stangierski J, Szczepka M, Taterczyński W (2014) Electronic ear circuit for the analysis of acoustic properties of food products, with the module of the peripheral hearing system operation hybrid simulation. PL Patent Application No P.409362

Remer T, Manz F (1995) Potential renal acid load of foods and its influence on urine pH. J Am Diet Assoc 95:791-797

Remer T, Dimitriou T, Matz F (2003) Dietary potential renal acid load and renal net acid excretion in healthy, free-living children and adolescents. Am J Clin Nutr 77(5):1255-1260. https://doi. org/10.1093/ajcn/77.5.1255

Robin F, Dubois C, Curti D, Schuchmann HP, Palzer S (2011) Effect of wheat bran on the mechanical properties of extruded starchy foams. Food Res Int 44:2880-2888. https://doi.org/10.1016/j. foodres.2011.06.041

Rybicka I, Gliszczyńska-Świgło A (2017) Minerals in grain glutenfree products. The content of calcium, potassium, magnesium, sodium, copper, iron, manganese, and zinc. J Food Compos Anal 59:61-67. https://doi.org/10.1016/j.jfca.2017.02.006

Salvador A, Varela P, Sanz T, Fiszman SM (2009) Understanding potato chips crispy texture by simultaneous fracture and acoustic measurements, and sensory analysis. LWT Food Sci Technol 42:763-767. https://doi.org/10.1016/j.1wt.2008.09.016

Schwalfenberg GK (2012) The alkaline diet: Is there evidence that an alkaline $\mathrm{pH}$ diet benefits health? J Environ Public Health 2012:727630. https://doi.org/10.1155/2012/727630

Scialla JJ, Anderson CAM (2013) Dietary acid load: a novel nutritional target in chronic kidney disease? Adv Chronic Kidney Dis 20(2):141-149. https://doi.org/10.1053/j.ackd.2012. 11.001

Shih MC, Kuo CC, Chiang W (2009) Effects of drying and extrusion on colour, chemical composition, antioxidant activities and mitogenic response of spleen lymphocytes of sweet potatoes. Food Chem 117(1):114-121. https://doi.org/10.1016/j.food chem.2009.03.084

Singha P, Singh SK, Muthukumarappan K, Krishnan P (2018) Physicochemical and nutritional properties of extrudates from food grade distiller's dried grains, garbanzo flour, and corn grits. Food Sci Nutr 6(7):1914-1926. https://doi.org/10.1002/fsn3.769
Spence C (2015) Eating with our ears: assessing the importance of the sounds of consumption on our perception and enjoyment of multisensory flavour experiences. Flavour 4:3. https://doi.org/10. 1186/2044-7248-4-3

Stangierski J, Poliszko S, Szczepka M, Mizgalski I (2016) An audiosensory intuitive analysis of the acoustic emission activity of food products. ABiD 21(3):146-158

Stojceska V, Ainsworth P, Plunkett A, Ibanoglu E, Ibanoglu S (2008) Cauliflower by-products as a new source of dietary fibre, antioxidants and proteins in cereal based ready-to-eat expanded. J Food Eng 87(4):554-563. https://doi.org/10.1016/j.jfoodeng. 2008.01.009

Sun-Waterhouse D, Wadhwa SS (2013) Industry-relevant approaches for minimising the bitterness of bioactive compounds in functional foods: a review. Food Bioprocess Technol 6:607-627. https://doi.org/10.1007/s11947-012-0829-2

Szczesniak A (2002) Texture is a sensory property. Food Qual Prefer 13(4):215-225

Szydłowska-Czerniak A, Szłyk E (2003) Spectrophotometric determination of total phosphorus in rape seeds and oils at various stages of technological process: calculation of phospholipids and non-hydratable phospholipids contents in rapeseed oil. Food Chem 81(4):613-619. https://doi.org/10.1016/S03088146(02)00562-9

Van Hecke E, Allaf K, Bouvier JM (1998) Texture and structure of crispy-puffed food products. II. Mechanical properties in puncture. J Text Stud 29:617-632. https://doi.org/10.1111/j.17454603.1998.tb00189.x

Villanueva NDM, Petenate AJ, Da Silva MAAP (2000) Performance of three affective methods and diagnosis of the ANOVA model. Food Qual Prefer 11:363-370. https://doi.org/10.1016/S09503293(00)00006-9

Wang P, Liu JC, Zhao QY (2002) Studies on nutrient composition and utilization of pumpkin fruit. J Inner Mongolia Agr Univ 23:52-54

Wójtowicz A, Pasternak E, Juśko S, Hodara K, Kozłowicz K (2012) Selected quality characteristics of extruded corn snacks with defatted flaxseeds addition. Acta Sci Pol Technica Agraria 11(3-4):25-33

Yadav M, Jain S, Tomar R, Prasad G (2010) Medicinal and biological potential of pumpkin: An updated review. Nutr Res Rev 23:184-190. https://doi.org/10.1017/S0954422410000107

Zdrojewicz Z, Błaszczyk A, Wróblewska M (2016) Pumpkin healthy, but forgotten (In Polish: Dynia—zdrowa, ale zapomniana). Med Rodz 19(2):70-74

Zhang F, Jiang ZM, Zhang EM (2000) Pumpkin function properties and application in food industry. Sci Technol Food Ind 21:62-64

Zielinski H, Kozlowska H, Lewczuk B (2001) Bioactive compounds in the cereal grains before and after hydrothermal processing. Innov Food Sci Emerg Technol 2(3):159-169. https://doi.org/10. 1016/S1466-8564(01)00040-6

Publisher's Note Springer Nature remains neutral with regard to jurisdictional claims in published maps and institutional affiliations. 